\title{
ELUCIDATING EU ENGAGEMENT: RETHINKING DIMENSIONS OF SUPRANATIONAL PARTICIPATION
}

\author{
Nicholas Clark \\ Assistant Professor \\ Department of Political Science \\ Susquehanna University \\ clarkn@susqu.edu \\ K. Amber Curtis \\ Assistant Professor \\ Department of Political Science \\ Clemson University \\ acurti2@clemson.edu
}

***DRAFT: PLEASE DO NOT CIRCULATE OR CITE WITHOUT PERMISSION***

\begin{abstract}
Some observers of the EU have expressed concern about the quality of its democratic governance. Such sentiments are reflected in much of the research conducted on attitudes toward the EU and voting in European Parliament elections, both of which seek to assess the vibrancy of public engagement with the European project. Yet few-if any-have considered other types of behavior that may be associated with an active EU citizenry. This paper uses original survey data from the United Kingdom to complement existing research by identifying a fuller picture of the types and frequency of EU participation. We also assess the extent to which predictors from existing public opinion literature (identity threat, economic concerns, political attitudes and sociodemographics) predict these various types of participation. Results suggest that citizens pursue a wide array of participation avenues and that different sets of motivations underpin these different types of EU engagement.
\end{abstract}

KEYWORDS: European identity, political participation

Paper prepared for the $14^{\text {th }}$ Biennial Conference of the European Union Studies Association, March 5-7, 2015 in Boston. K. Amber Curtis gratefully thanks Opinium Research, LLP for its assistance administering this survey, made possible by funding from the Colorado European Union Center of Excellence and the Center for British and Irish Studies at the University of Colorado Boulder. 
Since the Danish rejection of the Treaty of Maastricht in the early 1990s, scholars have intensely debated the democratic quality of the European Union (EU) — or lack thereof. Many point to the public's apparent lack of desire to engage at the European level and claim that the EU suffers from a 'democratic deficit' and the absence of a lively public sphere (e.g., Rorschneider 2002; Schmitter 2000). Empirical investigations in this vein have been largely limited to two types of mass political behavior at the European level: voting in European Parliament (EP) elections and general support for (or opposition to) European integration. But are these the only avenues through which EU citizens might "engage" with the EU? We argue no: there exist a number of other behaviors that might reflect a vibrant European citizenry. To better understand if and how the public engages with the EU, we develop a theoretical framework to identify multiple types of participation and then examine patterns of behavior to test whether our expectations hold.

More specifically, we assert that various types of behavior have been overlooked when it comes to measuring EU participation, and that these different acts-some positive, some negative-should be taken into account in order to produce a full picture of European engagement. We expect, first, that similar types of behavior will cluster together and, second, that these resulting modes of behavior may be explained by slightly different combinations of factors. After reviewing the basics of political participation in Europe, we develop a conceptual framework to account for four different categories through which participation may take place: information-seeking, expressions of pride, taking advantage of EU benefits, and protest. A fifth category applies to those who intentionally choose not to participate. We test the validity of these different dimensions using original data from a nationally-representative Political Attitudes and Identities Survey conducted in the United Kingdom (UK) in 2012. Upon confirming the existence of these various factors, we then employ existing explanatory models to determine the 
extent to which established motivations like identity threat, economic concern, and political attitudes explain each type.

Our findings contribute to scholarly understanding of democratic behavior within a complex, multilevel polity like the European Union. The prior emphasis on voting behavior and public opinion within EU studies makes sense as the former is the most conventional form of participation while the latter offers a clear indicator of citizens' perceptions of and satisfaction with the EU. However, we believe there is much to gain from now analyzing and comparing multiple other types of participation. These efforts will then allow us to better comprehend just how (dis)engaged the public is with the EU, and why.

\section{PARTICIPATION AT THE EUROPEAN LEVEL}

Much of the research on EU-based political participation focuses on voting in elections to the European Parliament (EP). Evidence suggests that the public behaves quite differently at the national versus European levels. Citizens have consistently demonstrated far less interest in EP elections than national ones. In most countries, turnout is significantly lower at the European level and has declined in each successive European election, from its high of $62 \%$ in 1979 to its lowest-ever rate of $42.6 \%$ in 2014 ("Results of the 2014 European Elections"). Some of the predictors of turnout in national elections have been found to also influence participation at the European level; compulsory voting and weekend voting, for instance, correspond with increased turnout at both levels (Franklin, et al 1996, Smith 1999; Mattila 2003). Other predictors of EP turnout are unique to the European Union. Individual-level analyses suggest that trust in the European Parliament and the EU more broadly promotes greater participation in EP elections (Blondel, et al 1998, Clark 2014). Other macro-level analyses similarly indicate that EP turnout increases along with aggregate levels of EU support and the amount of subsidies a country receives from the EU (Mattila 2003, Stockemer 2012). 
Additionally, those that choose to vote often use EP elections as a forum to engage the national political sphere rather than as instruments of accountability at the European level (Reif and Schmitt 1980). Some individuals take EP elections as an opportunity to support a lesscompetitive party that they prefer, but on which they would not waste their vote in a (more consequential) national election. Other individuals use EP elections to signal disapproval with the incumbent government's performance since the last national election. While this secondorder elections theory is supported by a large body of evidence (e.g., Anderson and Ward 1996, Marsh 1998, Carrubba and Timpone 2005, Schmitt 2005, Koepke and Ringe 2006, Marsh 2007), more recent contributions find that some voters do use EP elections as an opportunity to address concerns about the EU (and not just the national government). Defections from a governing party to an opposition party in EP elections are more likely to occur if government supporters perceive of themselves as more Eurosceptic than the government (Hobolt, et al 2009) or disapprove of the government's performance on EU issues (Clark and Rohrschneider 2009). Altogether, whether voters engage in second-order behavior or, instead, actually consider the EU when making their EP vote choices, appears to depend on the broader information environment in which they are embedded. EP voters are more motivated by EU concerns when and where EP political campaigns, the media, and the national political environment provide more information about EU affairs (Weber 2007, Hobolt, et al 2009, de Vries, et al 2011, Hobolt and Spoon 2012).

There are a number of similarities between the research agendas on EP elections and referenda on the EU (see Hobolt 2006). Some scholars argue that attitudes about the EU influences vote choices in EU referenda (Svennson 2002, Mendez, et al 2014), while others maintain that EU referenda resemble second-order elections by serving as a barometer of support for the national government (Franklin, et al 1994, Garry, et al 2005). More recent contributions have examined the effects of specific attitudinal judgments about the EU. For instance, perceiving that the EU threatens national culture increases the likelihood of a vote against further 
integration in EU referenda (Lubbers 2008). In a similar vein, referenda voters who are prone to anxiety or fearfulness are more likely to vote based on the issue in question, while those operating in a state of anger are more likely to adhere to the second-order expectations (Garry 2014). Much as with the research on EP elections, the work on referenda has evolved to consider how the political context might prompt referenda voters to focus more on EU concerns when casting a ballot. For instance, individuals behave more consistently with the second-order model when elites opt to hold a referendum due to political calculations (as opposed to a legal mandate) and when the results are non-binding (Hug and Sciarini 2000, Hug 2002). Additionally, political environments that better educate the public about the EU-such as in countries with greater political contestation over the issue of European integration (Franklin 2002, Hobolt 2005) or in which elites more frequently address this issue (Hobolt 2007)—produce referenda voters who are motivated more by EU concerns.

Far less attention has been devoted to other types of political participation at the European level. A few studies have focused on describing non-traditional forms of collective action (such as protests, demonstrations and strikes) targeted at affecting policies made in the European Union. In one such contribution, Imig (2002) finds that, while relatively few protests between 1984 and 1997 were focused on the EU, the number of such events increased throughout the 1990s as the EU grew more salient to the public. Reising (1999) similarly observes spatial and temporal diffusion effects to EU protests, with protests spilling over national borders and increasing in number over time. However, contrary to the expectations of an everincreasing EU protest culture, Uba and Uggla (2011) show that the number of 'Europrotests' began to decline after 2002. By 2007, the frequency of EU-based protests declined to the numbers observed a decade earlier. As to the motivations behind collective action at the EU level, Imig (2002) suggests that fears over the economic implications of European integration motivate many protest groups. Given the scarcity of research on protests and (so far as we are 
aware) the absence of research on forms of supranational political participation other than voting, we still know very little about whether, how, and why the public interacts with the European Union.

The emphasis on voting within the literature on democratic behavior at the EU level makes sense both because voting data is more readily available and the act of voting is the form of participation most often associated with the rights and responsibilities of democratic citizenship. Yet, in most advanced industrial democracies, turnout in elections is declining (Gray and Caul 2000) and individuals are increasingly seeking out new and different outlets to participate in the political process (Dalton 2000). Recognizing that individuals often seek alternatives to the ballot box to express themselves, Verba, Nie and Kim (1978) developed a typology to conceptually organize different modes of participation. The early form of this typology included voting, campaign activity, contacting individuals directly, and communal activities. Dalton (2013) updates the typology to also include protest activities and internet-based activism. ${ }^{1}$ Each of these six types encompasses several participatory acts; campaign activity, for instance, includes giving money to a political candidate, attending a party meeting, or trying to persuade another voter. Different actions are classified under a particular type according to the likely influence of the act on decision-makers, the degree of partisan conflict involved, the effort required on the part of the individual, and the necessity to cooperate with others. Given the low turnout in European elections and the declining use of electoral mechanisms more broadly, we believe a more well-rounded assessment of democracy at the European level must take into account a broader range of participatory acts such as those introduced in the Verba, Nie and Kim (1978) and Dalton (2013) typologies.

\footnotetext{
1 The internet has undoubtedly changed the nature of traditional participation while simultaneously opening new venues for engagement (e.g., Krueger 2002). An emerging vein of research explores variation in who participates online versus in person (e.g., Vicente and Novo 2014).
} 


\section{RETHINKING HOW CITIZENS “ENGAGE” WITH THE EU}

Building off the typologies above, we differentiate between modes of participation according to an individual's likely motivations for engaging with the European Union. Some individuals may act with the intention of affirming the value of the European project through expressions of pride, while others may seek out forms of participation, such as protest, or blatant non-participation, that signal their mistrust of, apathy towards, or perhaps even opposition to that project. Some participatory acts may be nothing more than an individual seeking to learn more about the European Union. Other acts may have a more utilitarian basis with individuals simply taking advantage of the opportunities created by European integration such as travelling to another EU country. Our resulting five-part classification schema differs from Verba, Nie and Kim (1978) and Dalton (2014) in that some of these modes of participation do not involve efforts to actively influence political processes (although even their typologies allows for communal activities). However, each of these modes involves inherently political activities where individuals are in some way interacting with or making use of political actors and processes at the European level. These are also modes of participation that we might expect from individuals fulfilling the role of a democratic citizenry, meaning that (in addition to voting) individuals seek out information about the political process, articulate their preferences through a variety of mechanisms and interact with others from the larger political community.

Thus, our conceptual framework argues that specific types of behavior can be classified together under four modes of participation: information-seeking, expressions of pride, taking advantage of opportunities created by European integration, and protest behavior. For example, contacting one's MEP would be considered information-seeking; celebrating Europe Day constitutes an expression of pride; travelling within Europe constitutes taking advantage of some of the many opportunities created by the EU; and protesting against the EU falls within its own 
category. Additionally, we believe that a handful of citizens may actively choose not to participate in any way, which constitutes our fifth category.

\section{BASELINE EXPLANATIONS OF PARTICIPATION}

Beyond examining whether the structure of participation does, indeed, break down into multiple dimensions, we seek to apply known explanations to investigate how well existing findings travel across these domains of EU engagement. Political participation-whether studied in its voting behavior or public support forms, and regardless of whether studied in the European or United States context - appears motivated by four sets of factors: economic concerns, identity threat general political interest and opinions, and demographic characteristics.

The standard model of almost any form of political participation begins with expectation that individuals will engage when doing so rationally benefits them. In support of this claim, individual-level positions on the EU are influenced by the actual and perceived economic costs and benefits of European integration (Eichenberg and Dalton 1993, Gabel and Palmer 1995, Anderson and Reichert 1995, Brinegar, et al 2004, Eichenberg and Dalton 2007). More specifically, EP vote choice is commonly attributed to retrospective voting where citizens use their economic circumstances to evaluate the options in front of them (e.g., Kousser 2004).

Both partisan and political-territorial identification are known to determine one's broader sociopolitical outlook and engagement (e.g., Green, Palmquist, and Schickler 2004). Social identity can incentivize participation when group interests are perceived to be at stake- or when they believe their efforts will help produce a positive outcome for their preferred group (Fowler and Kam 2007). In the European sphere, research often suggests that strong national attachments promote anxieties about the deterioration of national culture due to EU-level pressures and thus undermine EU support (Carey 2002, Christin and Trechsel 2002, McLaren 2002, Kritzinger 2003). Other works maintain that individuals may hold loyalties to multiple communities 
simultaneously and that overlapping identities may in fact be mutually reinforcing (Van Kersbergen 2000, Habermas 2001, Haesly 2001, Diez Medrano 2003, Klandermans, et al 2003). ${ }^{2}$

At a minimum, identity attachments filter individuals' perceptions of the EU-and typically more so than economic explanations (e.g., Hooghe and Marks 2004). Given such findings, we believe that identity may well influence other types of behavior. We expect that the strength of an individual's attachment to local, national and European communities influences the extent to which they participate at the European level. Such attachments likely increase both the desire to participate (and thereupon affirm one's position within the community) and a sense of obligation to contribute to the larger community. While prevalent in the literature on EU support, identitybased explanations are rarely considered within the research on EU-level participation. ${ }^{3}$ Yet one can imagine that identity has a strong effect on both traditional and non-traditional forms of participation. Those individuals that identify strongly with the EU may be more likely to seek out information about EU politics or to express pride in the European project out of a sense of civic duty. In contrast, stronger attachments to local or national communities may motivate protesters against the EU who are fearful that the EU threatens the cultural integrity or political influence of those communities. In fact, we expect that strong local and national identities influences all but one of the four modes of participation from our conceptual framework; the exception being those who take advantage of opportunities created by European integration. This category encompasses relatively value-free behaviors. For example, while especially xenophobic individuals may be less likely to travel outside of their own borders, we expect that individuals will likely make use of the freedom to travel within the EU regardless of their particular political

\footnotetext{
${ }^{2}$ The precise effect of identity-based considerations likely depends on the political context. In many EU countries, Eurosceptic elites have sought to activate and/or aggravate fears about the EU's effects on national identity (Kopecky and Mudde 2002; Marks, et al 2006). When and where these elites have acquired greater visibility in the media and in the political sphere, the public has been more likely to consider the EU as a liability for national culture (Hooghe and Marks 2004).

${ }^{3}$ See Lubbers (2008) for an exception.
} 
identity. Additionally, this category includes voting in EP elections, a form of behavior that has not been found to be influenced by identity-related considerations in past research.

On the political side, several attitudes and orientations might contribute to how involved citizens are. Political interest is a standard prerequisite of participation (Brady, Verba, and Schlozman 1995). Following the news - at least in print form-can make individuals more participatory (McLeod, Scheufele, and Moy 1999). In Europe, attitudes towards the EU affect behavior at the European level; for instance, voting in EP elections is higher in countries with greater support for EU membership (Mattila 2003). And, as already discussed above, European engagement often reflects second-order motivations rather than explicitly EU-related concerns.

Lastly, socioeconomic status is a nearly undisputed cause of (non)participation (Leighley 1995; Verba and Nie 1972; Verba, Schlozman, and Brady 1995). Yet SES is itself a function of one's resources and civic skills, as acquired through age, education, income, etc. (Brady, Verba, and Schlozman 1995). Thus, following the past behavior research (e.g., Lewis-Beck et al. 2008), increasing levels of education, income, and occupational prestige should correspond with greater participation across the different modes. In addition, a 'gender gap' often emerges for political involvement with men being much more politically active than women (e.g., Inglehart and Norris 2000; Verba, Burns, and Schlozman 1997). Therefore, we expect males to be more engaged than females.

\section{DATA \& METHOD}

Because existing datasets have not included all the items with which to test our expectations, we utilize data from an original Political Attitudes and Identities Survey (PAIS) conducted in the United Kingdom during summer 2012. ${ }^{4}$ A London-based polling firm

\footnotetext{
${ }^{4}$ The UK is renowned for being the most eurosceptic EU member state (Spiering 2004). While our case selection is primarily motivated by data availability, we propose that this fact actually makes it the best place to study EU
} 
administered the survey online by inviting almost 7,000 of its standing panelists to participate; over $2,000 \mathrm{did}$ for a total response rate of nearly $31 \%$. To ensure that the ultimate sample was nationally representative, the polling firm weighted the final results according to national targets for gender, age, social class, employment status, and geographic region based on data from the Office for National Statistics ${ }^{5}$ and National Readership Survey. ${ }^{6}$

\section{Dependent Variable: Capturing Participation}

Most importantly, our survey included the following question: "In which, if any, of the following activities have you personally taken part? (Please select all that apply)," followed by fourteen potential activities - which were then presented as randomized options-for respondents to check off or leave blank in order to express their degree of EU engagement. Figure 1 presents the percentages of responses to these various items and suggests, as is to be expected, quite a bit of variation in the types of actions citizens take toward the EU. For most aspects, participation is indeed quite low. For instance, only $1.2 \%$ of respondents indicated that they had purchased an EU flag and only 1.45\% reported that they had celebrated 'Europe Day' on May 9th. For other items, participation is relatively high: $60.7 \%$ of respondents said they had used the Euro currency and $64.74 \%$ traveled to another EU country. ${ }^{7}$ Interestingly, $11.34 \%$ of respondents marked that they had done nothing, perhaps — as we argue — openly indicating their true apathy toward engaging with the EU.

\section{[FIGURE 1 ABOUT HERE]}

Given this variation, we clearly need to answer the question of whether it is the same individuals participating in each of these numerous dimensions of participation, or whether

engagement. Since so few UK citizens do engage with the EU, we can be that much more confident of any significant relationships that do emerge.

${ }^{5} \mathrm{http} / / / \mathrm{www}$. ons.gov.uk/ons/index.html

${ }^{6} \mathrm{http}: / /$ www.nrs.co.uk/

${ }^{7}$ In the middle range, $31.77 \%$ claimed they had voted in the 2009 European Parliament elections. This closely matches the actual UK turnout rate of $34.7 \%$ according to the European Parliament website (http://www.europarl.europa.eu/aboutparliament/en/000cdcd9d4/Turnout-\%281979-2009\%29.html). 
different individuals are participating in different ways. To get at this, we generated an additive index of the thirteen possible EU participation items (excluding the 'Did Nothing' option). ${ }^{8}$ Figure 2 graphs the results. The mean level of EU participation per person is two items (1.92; s. d. $=1.53$ ), while $0.05 \%$ of our sample reported having engaged in all items. This lends credence to our argument that people engage with the EU in different ways, as opposed to supporting the idea that certain individuals are, by nature, participators who engage in all kinds of ways while others are not. Importantly, nearly $23 \%$ of respondents did not participate in any way-and yet did not purposely assert that they did nothing but marking that survey option. This further validates our assertion that some citizens actively choose not to participate in EU affairs, which is - in its own way - then a dimension of EU engagement that should be analyzed separately from other types of participation.

[FIGURE 2 ABOUT HERE]

\section{Covariates: Explaining Participation}

For our later analyses, we draw on extant findings surrounding the general determinants of participation (particularly in the EU case) to inform the potential explanatory variables we include. These can be summarized into four categories: identification, economic concerns, political considerations, and sociodemographics. ${ }^{9}$

In terms of identity, our PAIS asked respondents, "We are all part of different groups. Some groups are more important to us than others when we think of ourselves. How important are each of the following in describing how you personally see yourself? Please consider the following scale, where 7 means that you identify very strongly with it and 1 means that you do not identify with it at all." They then rated their degree of identification with a series of politicalterritorial levels: their town or village (Local Identification), their region (Regional

\footnotetext{
${ }^{8}$ This set of items produces respectable reliability: the Cronbach's alpha is 0.612 . It increases to 0.658 when Did Nothing is also included.

${ }^{9}$ The Appendix provides descriptive statistics for each variable.
} 
Identification), the United Kingdom (National Identification), and Europe (European Identification).

Economically, we asked respondents, "In the past year, how well do you think things have been going when it comes to...1) The economic situation in the United Kingdom? 2) The financial situation of your household? 3) The employment situation in the United Kingdom? 4) Your personal job situation?" For each item, respondents indicated whether they perceived things to be going very poorly, fairly poorly, fairly well, or really well. The resulting Egocentric Index is a mean index combining items 2 and 4 while our Sociotropic Index is a mean index based on items 1 and 3. Both indices range from one to four with seven possible values in between.

We operationalize political motives for EU participation in several ways. First, the $E U$ Support Index is a mean index ranging from one to seven with 25 possible values based on agreement or disagreement on a scale of one (strongly disagree) to seven (strongly agree) with four items: “Generally speaking, the United Kingdom's membership in the European Union is a good thing," "Taking everything into consideration, the United Kingdom has on balance benefitted from being a member of the European Union," "The European Union conjures up a very positive image for me," and "The United Kingdom should leave the European Union altogether." ${ }^{10}$ Similarly, Current EU Direction measures agreement (on the same 1-7 scale) with the statement, "At the present time, things are going in the right direction in the European Union." ${ }^{11}$ L-R Ideology captures individuals' self-placement on a standard 11-point ideological scale $(0=$ far left; $10=$ far right $)$. We tap Political Interest by reverse coding respondents' level of agreement with the statement, "I am not at all interested in politics." The resulting variable

\footnotetext{
${ }^{10}$ This last item was recoded prior to constructing the index so that higher responses indicated a stronger preference for staying in the EU.

${ }^{11}$ We include Current EU Direction separately from the EU Support index because it taps citizens' specific views toward the EU at that moment in time, whereas the latter is meant to gauge more general (aka diffuse) support for European integration overall.
} 
ranges from low interest (one) to high interest (seven). Likewise, Follow News is based on agreement (on the same one to seven scale) with the statement, "I follow the news regularly." And finally, PM Approval ranges from one to seven based on agreement that, "Prime Minister David Cameron is doing a good job."

Lastly, we include a series of sociodemographic variables. Gender is measured as a dummy variable equal to one for Male. Education ranges from zero (none) to five (advanced degree). Age ranges from 18 to 81. Occupational Prestige ranges from one (employed in an unskilled or semi-skilled manual occupation) to five (employed in a higher managerial/professional/administrative profession). Rural-Urban Residence reflects whether someone reports living in a rural area or village (one) versus a large town or city (four). And then we use separate dichotomous variables to isolate those who are Unemployed or Employed FullTime.

\section{DESCRIPTIVE RESULTS: DIMENSIONS OF EU ENGAGEMENT}

We first conduct principal-components factor analysis of the various participation items to test our theoretical expectation that EU engagement can be broken down into multiple dimensions beyond just voter turnout and generic support. A four-factor solution emerges, supporting our conceptual framework. Table 1 organizes each item according to the factor onto which it loaded most highly following orthogonal varimax rotation. Seven items load onto Factor 1, nearly all of which seem based around aspects of participation through which individuals seek out and/or receive information about the EU: contacting one's Member of European Parliament (MEP); contacting or visiting a local European Commission representation office; visiting the EU's website; having been contacted by an interest group (e.g., trade federations, companies, non-governmental organizations, national associations, regional representations, think tanks, etc.) regarding a European-wide issue; having received mail from an 
EU institution (e.g., the Commission, the Parliament, etc.); and hearing the EU's anthem. The one exception is that the explicit 'None of the Above' item (aka Did Nothing) also loads best here - albeit, negatively while all the rest load positively.

\section{[TABLE 1 ABOUT HERE]}

Factor 2 is comprised of voting in the 2009 EP elections, traveling to another European country, and using the euro currency; these largely reflect ways in which citizens can personally take advantage of some of the benefits offered by EU membership. Studying abroad through the ERASMUS program, celebrating Europe Day, and purchasing an EU flag make up Factor 3. We interpret these items as ways in which citizens may express their EU pride. Lastly, as expected, only one item loads onto Factor 4: participating in a protest against the EU-clearly an expression of anti-EU sentiment.

Based on these confirmatory results, we proceed with analyzing whether different determinants explain the different modes of EU engagement. In addition to the Additive Index discussed above, we generate additional dependent variables based on additive indices of the items in each factor: Info-Seeking (alpha =0.571), Take Advantage $($ alpha $=0.665)$, Show EU Pride $($ alpha $=0.329)$, and Protest Against the EU. ${ }^{12}$ Given its negative loading and the initial results above appearing to differentiate those who purposely admit they did nothing from those who simply checked none of the participation items, we do not include Did Nothing into the Info-Seeking category and instead assess it on its own. We use OLS for four of the dependent variables (Additive Index, Info-Seeking, Take Advantage, and Show EU Pride) and ordered logit as needed for the other two (Protest Against the EU and Did Nothing). In each case, we use

\footnotetext{
${ }^{12}$ We report the resulting ranges, means, and standard deviations in the Appendix.
} 
robust standard errors clustered by respondents' region in order to account for sampling procedures. $^{13}$

\section{CAUSAL ANALYSIS: EXPLAINING VARIATION IN TYPES OF EU ENGAGEMENT}

Tables 2 and 3 present a series of models to parse out the primary explanation(s) behind each different dimension of EU participation. To reiterate, our categories of covariates are intended to capture each of the predominant explanations from existing findings on EP voting and public support for European integration. Thus, at this stage we are not attempting to add novel explanations to explain why citizens engage with the EU, but are instead focused on testing competing arguments from extant literature to better understand how these various sets of motivations might lead individuals to pursue fundamentally different avenues of EU participation. Importantly, apart from certain sociodemographic features (which are the most consistently significant set of predictors), different elements seem to explain each model. In other words, there is little consistency across models regarding the primary determinant of partaking in that type of participation.

\section{[TABLE 2 ABOUT HERE]}

The determinants of European engagement in general (Additive Index: Table 2, Model 1), closely match existing findings from the literature. More variables attain statistical significance here than in any other model. Rather than discuss each model item by item, we offer a number of figures portraying the substantive impact of the significant predictors in order of greatest to least from each model (Figures 3-8). As shown in Figure 1, education has the strongest effect on one's overall level of participation in EU affairs; moving from having no education to holding an advanced degree increases engagement by 1.03 on the $0-13$ scale. Support for the European

\footnotetext{
${ }^{13}$ There is no variance at the regional level for in any dependent variable, therefore we do not use multilevel modeling.
} 
integration and age follow closely behind. National identification has the smallest impact (only 0.2 ), yet a positive one nonetheless. Unsurprisingly, citizens are more likely to engage with the EU when they are politically interested, feel secure in their egocentric economic situation, and identify with Europe. Only two variables have a negative effect on participation: those who think the EU is currently going in the right direction and are more approving of their current national government are less likely to report having done much at the EU level.

\section{[FIGURES 3-6 ABOUT HERE]}

Interesting findings emerge when we decompose participation into its various dimensions. For instance, sociotropic economic concerns only matter when it comes to seeking out information about the EU (Table 2, Model 2 and Figure 4); the more one is worried about the national economic and employment situation, the less likely they are to turn to the EU. This isn't the substantively strongest motivation behind Info-Seeking; education retains first place followed by European identification. The factors behind taking advantage of things the EU has to offer (e.g., traveling within the EU, using the euro, and voting in EP elections) look most like the determinants of participation in general. As depicted in Table 1, Model 3 and Figure 5, age and support for integration have fairly strong positive effects (producing approximately a 0.8 change in Take Advantage on a 0-3 scale) while believing the EU is presently going in the correct direction reduces the likelihood of participation by almost as much. And then engaging in acts that display one's pride in the EU is affected by some things that do not show up elsewhere (Table 2, Model 4 and Figure 6). Ideology matters only here, and in a somewhat counterintuitive fashion: more right-leaning individuals appear more likely to do things like studying abroad through ERASMUS, celebrating Europe Day, or buying an EU flag. This is also the only participation dimension affected by regional identification. It has a negative impact that, substantively, almost identically rivals the positive one produced by European identification. However, the magnitude of effects of all predictors in this model is extremely small: the 
strongest determinant - age (which operates in a negative fashion in this model, likely based on the age requirements for studying abroad) — only produces a -0.12 change in Show EU Pride on a 0-3 scale while the weakest—regional identification — reduces the predicted value by -0.06 .

\section{[TABLE 3 ABOUT HERE]}

Table 3 isolates the determinants of the dichotomous participation acts. Very few of ths standard predictors explain protesting against the EU (Model 5 and Figure 7). Expectedly, higher EU support is negatively related to protest-but even moving from the minimum to the maximum value of EU support only reduces the predicted probability of protest by $-2.8 \%$. Education and being male are associated with greater likelihood of engaging in a protest, but with even smaller substantive effects $(1.8 \%$ and $0.9 \%$ respectively). Finally, the standard explanations for participation in general are negatively associated with explicitly admitting to doing nothing (Model 6 and Figure 8). The most important determinant is Current EU Direction: those who think everything is completely fine with how the EU is presently operating have a $17.3 \%$ greater predicted probability of answering this item affirmatively than their counterparts who are most dissatisfied with the EU's present state.

\section{[FIGURES $7 \& 8$ ABOUT HERE]}

All in all, our findings suggest that different types of EU engagement are motivated by different things. Very few predictors are consistently significant across all models; only some basic sociodemographic characteristics appear to explain every kind of participation. Education is the only variable that matters in every single case, and it appears to have the strongest substantive impact in many instances. But beyond that, identity explanations have no effect when it comes either taking advantage of EU benefits or protesting against the EU. Economic concerns play no role in several models, and where they do it appears egocentric anxieties outweigh sociotropic fears. General attitudes towards the EU are fairly reliable gauges of how involved one might be at the EU level; one's overall support for integration affects multiple avenues of 
EU engagement, such that people with greater EU support then participate more in EU-related affairs. Other political considerations (e.g., ideology, political interest, and prime minister approval) vary by model. Of our four sets of explanatory variables (identity, economics, politics, and sociodemographics), political attitudes are typically more important than other factors-but again, our big punchline is that no single category seems to explain all types of participation. Therefore, our results suggest that EU engagement, when broken down into its different possible avenues, is dependent on different aspects and therefore deserves much more nuanced attention from scholars.

\section{CONCLUSION}

Our analysis extends current work on political participation at the EU level in several ways. First, we offer a deeper conceptualization of how EU citizens might get engaged, beyond the standard focus on EP voting behavior and general support for European integration. Second, we affirmed this five-fold typology using original data. Our unique UK survey, and accompanying participation question, enabled us to probe fourteen different aspects of potential ways for citizens to get involved at the EU level. Factor analysis and descriptive statistics confirmed that different individuals engage in different types of activities: information seeking, taking advantage of EU opportunities, showing EU pride, protest, and deliberate nonparticipation. We assert that this last dimension is especially important to consider and is, to our knowledge, something as of yet unexplored in extant work. Third, our causal analysis tested the four predominant explanations of participation prevalent in existing literature (economic concerns, identity attachments, political views, and sociodemographic characteristics) in order to test expectations about which category most motivates each of the five types of participation. We show that, both statistically and substantively, the causes of EU engagement vary depending on the type of activities in question - and that examining all items together in one overarching 
participation index overlooks important variation in which determinants have the largest impact. While many sociodemographic items — particularly education — almost always play a role, things like identity (which is further broken down into numerous political-territorial levels), economic anxiety (separated into its egocentric and sociotropic components), and EU support (both in general and in regards to specific assessments of the EU's current direction) only matter in certain cases.

Altogether, we are hopeful that our efforts will encourage scholars and policymakers to view EU engagement in a more holistic light and to target their efforts to boost democratic involvement by focusing on the specific mechanisms underlying the various modes of participation. For instance, citizens' identification matters mostly when it comes to showing EU pride, and contradicting tendencies emerge with those who report feeling European more likely to do things like celebrate Europe Day while those with strong regional identity much less likely to do so. Or, take the example of protesting against the EU. In our models, this act is most affected by citizens' underlying attitudes towards integration-not economic concerns (as posited by previous literature). Similarly, citizens seem most likely not to participate in any way when they think the EU is going in the right direction. While all our findings deserve greater scrutiny, this last aspect raises particularly interesting implications: perhaps the apparent lack of democratic EU engagement is simply a function of tacit consent with the current state of EU affairs and greater public involvement would actually signal greater discontent with the EU project.

While our investigation is limited by studying a single country (the United Kingdom) at a single time point (2012), we believe our findings offer new insight into what EU engagement looks like, what causes it, and what that means for evaluating the EU's democratic character. Future studies should extend our analyses by asking survey questions that can tap these 
numerous dimensions of EU participation in order to then afford a cross-national - and ideally cross-temporal—assessment of our tentative conclusions. 


\section{APPENDIX}

Table A1. Descriptive Statistics for Sample

\begin{tabular}{|c|c|c|c|c|}
\hline Variable (Range) & Mean & Std. Dev. & Min. & Max. \\
\hline \multicolumn{5}{|l|}{ Participation Variables } \\
\hline Additive Index & 2.022 & 1.529 & 0 & 13 \\
\hline Info-Seeking & 0.309 & 0.745 & 0 & 6 \\
\hline Take Advantage & 1.649 & 1.094 & 0 & 3 \\
\hline Show EU Pride & 0.042 & 0.234 & 0 & 3 \\
\hline Protest Against EU & 0.021 & 0.144 & 0 & 1 \\
\hline Did Nothing & 0.099 & 0.298 & 0 & 1 \\
\hline \multicolumn{5}{|l|}{ Identity Variables } \\
\hline Local Identification & 4.478 & 1.567 & 1 & 7 \\
\hline Regional Identification & 4.358 & 1.615 & 1 & 7 \\
\hline National Identification & 4.734 & 1.572 & 1 & 7 \\
\hline European Identification & 3.102 & 1.603 & 1 & 7 \\
\hline \multicolumn{5}{|l|}{ Economic Variables } \\
\hline Egocentric Index & 2.675 & 0.689 & 1 & 4 \\
\hline Sociotropic Index & 1.734 & 0.577 & 1 & 4 \\
\hline \multicolumn{5}{|l|}{ Political Variables } \\
\hline EU Support Index & 3.476 & 1.511 & 1 & 7 \\
\hline Current EU Direction & 2.596 & 1.450 & 1 & 7 \\
\hline L-R Ideology & 5.097 & 2.159 & 0 & 10 \\
\hline Political Interest & 4.712 & 1.909 & 1 & 7 \\
\hline Follow News & 5.440 & 1.546 & 1 & 7 \\
\hline PM Approval & 3.119 & 1.790 & 1 & 7 \\
\hline \multicolumn{5}{|l|}{ Sociodemographics } \\
\hline Male & 0.476 & 0.500 & 0 & 1 \\
\hline Education & 2.864 & 1.390 & 0 & 5 \\
\hline Age & 47.082 & 15.218 & 18 & 81 \\
\hline Occupational Prestige & 3.147 & 1.063 & 1 & 5 \\
\hline Rural-Urban Residence & 2.377 & 1.011 & 1 & 4 \\
\hline Unemployed & 0.029 & 0.169 & 0 & 1 \\
\hline Employed Full-Time & 0.492 & 0.500 & 0 & 1 \\
\hline
\end{tabular}




\section{REFERENCES}

Anderson, Christopher J. and Daniel S. Ward. 1996. "Barometer Elections in Comparative Perspective" Electoral Studies. 15(4): 447-460.

Anderson, Christopher and M. Shawn Reichert. 1995. "Economic Benefits and Support for Membership in the European Union: A Cross-National Analysis." Journal of Public Policy. 15: 231-249.

Blondel, Jean, Richard Sinnott, and Palle Svensson. 1998. People and Parliament in the European Union. Oxford, England: Oxford University Press.

Brady, Henry E., Sidney Verba, and Kay Lehman Schlozman. 1995. "Beyond SES: A Resource Model of Political Participation." American Political Science Review 89(2): 271-294.

Brinegar, Adam, Seth Jolly and Herbert Kitschelt. 2004. "Varieties of Capitalism and Political Divides over European Integration" in Gary Marks and Marco Steenbergen (eds.) European Integration and Political Conflict. Cambridge, England: Cambridge University Press.

Carey, Sean. 2002. "Undivided Loyalties: Is National Identity an Obstacle to European Integration?" European Union Politics. 3: 387-413.

Carrubba, Cliff and Richard J. Timpone. 2005. "Explaining Vote Switching Across First- and Second-Order Elections" Comparative Political Studies. 38(3): 260-281.

Christin, Thomas and Alexander Trechsel. 2002. "Joining the EU? Explaining Public Opinion in Switzerland" European Union Politics. 3: 415-443.

Clark, Nicholas and Robert Rohrschneider. 2009. "Second-Order Elections versus First-Order Thinking: How Voters Perceive the Representation Process in a Multi-Layered System of Governance" Journal of European Integration. 31(5): 645-664.

Clark, Nicholas. 2014. "Explaining Low Turnout in European Elections: The Role of Issue Salience and Institutional Perceptions in Elections to the European Parliament." Journal of European Integration 36(4): 339-356.

Dalton, Russell J. 2000. "Citizen Attitudes and Political Behavior" Comparative Political Studies. 33(6/7): 912-940.

Dalton, Russell J. 2013. Citizen Politics: Public Opinion and Political Parties in Advanced Industrial Democracies. CQ Press.

De Vries, Catherine E., Wouter van der Brug, Marcel H. van Egmond, and Cees van der Eijk. 2011. "Individual and contextual variation in EU issue voting: The role of political information" Electoral Studies. 30(1): 16-28.

Diez Medrano, Juan. 2003. Framing Europe: Attitudes to European Integration in Germany, Spain and the United Kingdom. Princeton, NJ: Princeton University Press. 
Eichenberg, Richard C. and Russell J. Dalton. 1993. "Europeans and the European Community: The Dynamics of Public Support for European Integration." International Organization. 47(4): 507-534.

Eichenberg, Richard and Russell J. Dalton. 2007. "Post-Maastricht Blues: The Transformation of Citizen Support for European Integration, 1973-2004." Acta Politica. 42(2-3): 128-52.

Fowler, James H., and Cindy D. Kam. 2007. "Beyond the Self: Social Identity, Altruism, and Political Participation." Journal of Politics 69(3): 813-827.

Franklin, Mark, Michael Marsh, and Christopher Wlezien. 1994. "Attitudes toward Europe and referendum votes: a response to Siune and Svensson." Electoral Studies. 13(2): 117-121.

Franklin, Mark, Cees van der Eijk, and Erik Oppenuis. 1996. "The institutional context: turnout." In Cees van der Eijk and Mark Franklin (eds.) Choosing Europe? The European Electorate and National Politics in the Face of Union. Ann Arbor, MI: Michigan University Press.

Franklin, Mark. 2002. "Learning from the Danish Case: A Comment on Palle Svensson's Critique on the Franklin Thesis' European Journal of Political Research. 54(6): 751-757.

Gabel, Matthew and Harvey Palmer. 1995. "Understanding Variation in Public Support for European Integration" European Journal of Political Research. 27(3): 3-19.

Garry, John, Michael Marsh, and Richard Sinnott. 2005. "Second order versus issue voting effects in EU referendums: evidence from the Irish Nice Treaty referendums" European Union Politics. 6(2): 201-221.

Garry, John. 2014. "Emotions and voting in EU referendums" European Union Politics. 15(2): 235-254.

Gray, Mark and Miki Caul. 2000. "Declining Voter Turnout in Advanced Industrial Democracies, 1950 to 1997: The Effects of Declining Group Mobilization" Comparative Political Studies. 33: 1091-1122.

Green, Donald, Bradley Palmquist, and Eric Schickler. 2002. Partisan Hearts and Minds: Political Parties and the Social Identities of Voters. New Haven: Yale University Press.

Habermas, Jurgen. 2001. The Postnational Constellation: Political Essays. Cambridge, MA: The MIT Press.

Haesly, Richard. 2001. "Euroskeptics, Europhiles and Instrumental Europeans: European Attachment in Scotland and Wales" European Union Politics. 2: 81-102.

Hobolt, Sara B. 2005. "When Europe matters: The impact of political information on voting behaviour in EU referendums" Journal of Elections, Public Opinion and Parties 15(1): 85-109. 
Hobolt, Sara B. 2006. "Direct Democracy and European Integration" Journal of European Public Policy. 13(1): 153-166.

Hobolt, Sara B. 2007. "Taking Cues on Europe? Voter competence and party endorsements in referendums on European integration" European Journal of Political Research. 46: 151182.

Hobolt, Sara B., Jae-Jae Spoon and James Tilley. 2009. “A vote against Europe? Explaining defection at the 1999 and 2004 European Parliament elections" British Journal of Political Science. 39(1): 93-115.

Hobolt, Sara B. and Jae-Jae Spoon. 2012. "Motivating the European voter: Parties, issues and campaigns in European Parliament elections" European Journal of Political Research. 51: 701-727.

Hooghe, Liesbet and Gary Marks. 2004. "Does Identity or Economic Rationality Drive Public Opinion on European Integration?” PS: Political Science and Politics. 37(3): 415-420.

Hug, Simon. 2002. Voices of Europe: Citizens, referendums and European integration. Boulder, CO: Rowman \& Littlefield.

Hug, Simon and Pascal Sciarini. 2002. "Referendums on European Integration: Do Institutions Matter in the Voter's Decision?" Comparative Political Studies. 33(1): 3-36.

Imig, Doug. 2002. "Contestation in the Streets: European Protest and the Emerging Euro-polity" Comparative Political Studies. 35(8): 914-933.

Inglehart, Ronald, and Pippa Norris. 2000. "The Developmental Theory of the Gender Gap: Women's and Men's Voting Behavior in Global Perspective." International Political Science Review 21(4): 441-463.

Klandermans, Bert, Jose Manuel Sabucedo and Mauro Rodriguez. 2003. "Inclusiveness of Identification among Farmers in the Netherlands and Galicia" found at http://www.unikiel.de/psychologie/ispp/doc_upload/klandermans_multiple_identities.pdf

Kritzinger, Sylvia. 2003. "The Influence of the Nation-State on Individual Support for the European Union.” European Union Politics 4(2): 219-41.

Lubbers, Marcel. 2008. 'Regarding the Dutch 'Nee' to the European Constitution: A Test of the Identity, Utilitarian and Political Approaches to Voting 'No'" European Union Politics. 9(1): 59-86.

Koepke, Jason R. and Nils Ringe. 2006. "The Second-Order Election model in an Enlarged Europe" European Union Politics. 7(3): 321-346.

Kousser, T. 2004. "Retrospective Voting and Strategic Behavior in European Parliament Elections." Electoral Studies 23(1): 1-21. 
Krueger, Brian S. 2002. "Assessing the Potential of Internet Political Participation in the United States." American Politics Research 30(5): 476-498.

Leighley, Jan E., and Arnold Vedlitz. 1999. "Race, Ethnicity, and Political Participation: Competing Models and Contrasting Explanations." The Journal of Politics 61(4): 10921114.

Leighley, Jan E. 1995. "Attitudes, Opportunities, and Incentives: A Field Essay on Political Participation.” Political Research Quarterly 48(1): 181-209.

Lewis-Beck, Michael S., William G. Jacoby, Helmut Norpoth, and Herbert F. Weisberg. 2008. The American Voter Revisited. Ann Arbor, MI: University of Michigan Press.

Marsh, Michael. 1998. "Testing the Second-Order Election Model after Four European Elections" British Journal of Political Science. 28(4): 591-607.

Marsh, Michael. 2007. "European Parliament Elections and Loss of Governing Parties" in van der Brug and van der Eijk (eds.) European Elections and Domestic Politics. 51-72. Notre Dame, IN: University of Notre Dame Press.

Mattila, Mikko. 2003. "Why bother? Determinants of turnout in the European elections" Electoral Studies. 22: 449-468.

McLaren, Lauren. 2002. "Public Support for the European Union: Cost/Benefit Analysis or Perceived Cultural Threat?” Journal of Politics. 64(12): 551-566.

McLeod, Jack M., Dietram A. Scheufele, and Patricia Moy. 1999. "Community, Communication, and Participation: The Role of Mass Media and Interpersonal Discussion in Local Political Participation.” Political Communication 16(3): 315-336.

Mendez, Fernando, Mario Mendez and Vasiliki Triga. 2014. Referendums and the European Union: A Comparative Inquiry. Cambridge, England: Cambridge University Press.

"Results of the 2014 European Elections." European Parliament (official website). http://www.europarl.europa.eu/elections2014-results/en/turnout.html. Accessed February $26,2015$.

Reif, Karlheinz and Hermann Schmitt. 1980. "Nine Second Order National Elections: A Conceptual Framework for the Analysis of European Election Results" European Journal of Political Research. 8:3-44.

Reising, Uwe K. H. 1999. "United in Opposition?: A Cross-National Time-Series Analysis of European Protest in Three Selected Countries, 1980-1995" Journal of Conflict Resolution. 43(3): 317-342.

Rohrschneider, Robert. 2002. "The Democracy Deficit and Mass Support for an EU-Wide Government." American Journal of Political Science 46(2): 463-75.

Schmitt, Hermann. 2005. “The European Parliament Elections of June 2004: Still Second 
Order?” West European Politics. 28: 650-679.

Schmitter, Philippe C. 2000. How to Democratize the European Union...And Why Bother? New York, NY: Rowman and Littlefield Publishers.

Smith, Julie. 1999. Europe's Elected Parliament. Sheffield, England: Sheffield Academic Press.

Spiering, Menno. 2004. “British Euroscepticism.” European Studies 20: 127-149.

Stockemer, Daniel. 2012. “Citizens' support for the European Union and participation in European Parliament elections” European Union Politics. 13(1): 26-46.

Svensson, Palle. 2002. "Five Danish referendums on the European Community and European Union: A critical assessment of the Franklin thesis" European Journal of Political Research. 41: 733-750.

Uba, Katrin and Frederik Uggla. 2011. "Protest Actions against the European Union, 1992-2007" West European Politics. 34(2): 384-393.

Van Kersbergen, Kees. 2000. "Political Allegiance and European Integration” European Journal of Political Research. 37: 1-17.

Verba, Sidney, and Norman H. Nie. 1972. Participation in America: Political Democracy and Social Equality. New York: Harper \& Row.

Verba, Sidney, Norman H. Nie and Jae-on Kim. 1978. Participation and Political Equality: A Seven-Nation Comparison. Chicago, IL: University of Chicago Press.

Verba, Sidney, Kay Lehman Schlozman, and Henry E. Brady. 1995. Voice and Equality: Civic Voluntarism in American Politics. Cambridge: Harvard University Press.

Verba, Sidney, Nancy Burns, and Kay Lehman Schlozman. 1997. "Knowing and Caring about Politics: Gender and Political Engagement.” The Journal of Politics 59(4): 1051-1072.

Vicente, María Rosalía, and Amparo Novo. 2014. “An Empirical Analysis of E-Participation: The Role of Social Networks and E-Government Over Citizens' Online Engagement." Government Information Quarterly 31(3): 379-387.

Weber, Till. 2007. "Campaign Effects and Second-Order Cycles: A Top-Down Approach to European Parliament Elections" European Union Politics. 8(4): 509-536. 
Table 1. Factor Analysis of Participation Items

\begin{tabular}{c|c|c|c}
\hline $\begin{array}{c}\text { FACTOR 1 } \\
(\mathbf{2 . 6 4 )}\end{array}$ & $\begin{array}{c}\text { FACTOR 2 } \\
\mathbf{( 1 . 7 7 )}\end{array}$ & $\begin{array}{c}\text { FACTOR 3 } \\
\mathbf{( 1 . 2 5 )}\end{array}$ & $\begin{array}{c}\text { FACTOR 4 } \\
\mathbf{( 1 . 0 0 )}\end{array}$ \\
\hline $\begin{array}{c}\text { Contacted MEP } \\
\text { Contacted EC } \\
\text { Rep. Office }\end{array}$ & $\begin{array}{c}\text { Voted in } \\
\text { '09 EP Elections }\end{array}$ & $\begin{array}{c}\text { Studied Abroad } \\
\text { through ERASMUS }\end{array}$ & $\begin{array}{c}\text { Protested Against } \\
\text { the EU }\end{array}$ \\
\hline $\begin{array}{c}\text { Traveled Within EU } \\
\text { Visited EU Website }\end{array}$ & $\begin{array}{c}\text { Celebrated } \\
\text { 'Europe Day' }\end{array}$ & \\
\hline $\begin{array}{c}\text { Contacted by } \\
\text { Political Group } \\
\text { About an EU Issue }\end{array}$ & Used the Euro & Bought an EU Flag & \\
\hline $\begin{array}{c}\text { Received Mail from } \\
\text { an EU Institution }\end{array}$ & & & \\
\hline Heard EU Anthem & & & \\
\hline Did Nothing & & & \\
\hline
\end{tabular}

Note: Factors' eigenvalues listed in parentheses.

Column entries report the factor onto which each item loaded most highly. 
Table 2. Determinants of Different Participation Dimensions

\begin{tabular}{|c|c|c|c|c|}
\hline & $\begin{array}{c}(1) \\
\text { Additive } \\
\text { Index }\end{array}$ & $\begin{array}{c}(2) \\
\text { Info- } \\
\text { Seeking }\end{array}$ & $\begin{array}{c}\text { (3) } \\
\text { Take } \\
\text { Advantage }\end{array}$ & $\begin{array}{c}(4) \\
\text { Show } \\
\text { EU Pride }\end{array}$ \\
\hline \multicolumn{5}{|l|}{ Identity Variables } \\
\hline Local Identification & $\begin{array}{l}-0.030 \\
(0.024)\end{array}$ & $\begin{array}{c}-0.019 \\
(0.020)\end{array}$ & $\begin{array}{l}-0.024 \\
(0.014)\end{array}$ & $\begin{array}{l}0.012 * \\
(0.006)\end{array}$ \\
\hline Regional Identification & $\begin{array}{l}-0.007 \\
(0.023)\end{array}$ & $\begin{array}{c}-0.014 \\
(0.015)\end{array}$ & $\begin{array}{c}0.016 \\
(0.011)\end{array}$ & $\begin{array}{c}-0.010 * * \\
(0.004)\end{array}$ \\
\hline National Identification & $\begin{array}{c}0.034 * * \\
(0.015)\end{array}$ & $\begin{array}{c}0.014 \\
(0.011)\end{array}$ & $\begin{array}{c}0.018 \\
(0.013)\end{array}$ & $\begin{array}{c}0.002 \\
(0.002)\end{array}$ \\
\hline European Identification & $\begin{array}{c}0.062 * * * \\
(0.020)\end{array}$ & $\begin{array}{c}0.046^{* *} \\
(0.015)\end{array}$ & $\begin{array}{c}0.008 \\
(0.010)\end{array}$ & $\begin{array}{c}0.011 * * \\
(0.004)\end{array}$ \\
\hline \multicolumn{5}{|l|}{ Economic Variables } \\
\hline Egocentric Index & $\begin{array}{c}0.130^{* *} \\
(0.048)\end{array}$ & $\begin{array}{c}0.042 \\
(0.032)\end{array}$ & $\begin{array}{c}0.085 * * \\
(0.034)\end{array}$ & $\begin{array}{c}0.005 \\
(0.010)\end{array}$ \\
\hline Sociotropic Index & $\begin{array}{l}-0.126^{*} \\
(0.064)\end{array}$ & $\begin{array}{c}-0.082 * * \\
(0.036)\end{array}$ & $\begin{array}{l}-0.058 \\
(0.043)\end{array}$ & $\begin{array}{c}0.021 \\
(0.016)\end{array}$ \\
\hline \multicolumn{5}{|l|}{ Political Variables } \\
\hline EU Support Index & $\begin{array}{c}0.171^{* * *} * \\
(0.035)\end{array}$ & $\begin{array}{c}0.041 * * \\
(0.017)\end{array}$ & $\begin{array}{c}0.130 * * * \\
(0.029)\end{array}$ & $\begin{array}{c}0.008 \\
(0.006)\end{array}$ \\
\hline Current EU Direction & $\begin{array}{c}-0.087 * * \\
(0.030)\end{array}$ & $\begin{array}{c}0.025 \\
(0.018)\end{array}$ & $\begin{array}{c}-0.127 * * * \\
(0.024)\end{array}$ & $\begin{array}{c}0.014 \\
(0.009)\end{array}$ \\
\hline L-R Ideology & $\begin{array}{c}0.020 \\
(0.021)\end{array}$ & $\begin{array}{l}-0.006 \\
(0.008)\end{array}$ & $\begin{array}{c}0.014 \\
(0.019)\end{array}$ & $\begin{array}{c}0.009 * * \\
(0.004)\end{array}$ \\
\hline Political Interest & $\begin{array}{c}0.070^{* * *} * \\
(0.021)\end{array}$ & $\begin{array}{c}0.007 \\
(0.009)\end{array}$ & $\begin{array}{c}0.067 * * * \\
(0.016)\end{array}$ & $\begin{array}{l}-0.006 \\
(0.005)\end{array}$ \\
\hline Follow News & $\begin{array}{c}0.050 \\
(0.033)\end{array}$ & $\begin{array}{l}0.034 * \\
(0.018)\end{array}$ & $\begin{array}{c}0.002 \\
(0.022)\end{array}$ & $\begin{array}{l}0.012^{*} \\
(0.006)\end{array}$ \\
\hline PM Approval & $\begin{array}{c}-0.039 * * \\
(0.015)\end{array}$ & $\begin{array}{c}-0.019 * * \\
(0.009)\end{array}$ & $\begin{array}{l}-0.018 \\
(0.015)\end{array}$ & $\begin{array}{c}-0.000 \\
(0.004)\end{array}$ \\
\hline \multicolumn{5}{|l|}{ Sociodemographics } \\
\hline Male & $\begin{array}{c}0.317 * * * \\
(0.070)\end{array}$ & $\begin{array}{c}0.145^{* * *} \\
(0.044)\end{array}$ & $\begin{array}{l}0.136^{*} \\
(0.065)\end{array}$ & $\begin{array}{c}0.022 \\
(0.013)\end{array}$ \\
\hline Education & $\begin{array}{c}0.206^{* * *} \\
(0.030)\end{array}$ & $\begin{array}{c}0.098 * * * \\
(0.016)\end{array}$ & $\begin{array}{c}0.088 * * * \\
(0.016)\end{array}$ & $\begin{array}{c}0.014 * * \\
(0.004)\end{array}$ \\
\hline Age & $\begin{array}{c}0.016^{* * *} \\
(0.003)\end{array}$ & $\begin{array}{c}0.004 * * \\
(0.002)\end{array}$ & $\begin{array}{c}0.013 * * * \\
(0.002)\end{array}$ & $\begin{array}{c}-0.002 * * * \\
(0.001)\end{array}$ \\
\hline Occupational Prestige & $\begin{array}{c}0.176^{* * *} \\
(0.033)\end{array}$ & $\begin{array}{c}0.028^{* *} \\
(0.011)\end{array}$ & $\begin{array}{c}0.150 * * * \\
(0.027)\end{array}$ & $\begin{array}{l}-0.005 \\
(0.004)\end{array}$ \\
\hline Rural-Urban Residence & $\begin{array}{c}0.009 \\
(0.047)\end{array}$ & $\begin{array}{l}-0.009 \\
(0.029)\end{array}$ & $\begin{array}{c}0.016 \\
(0.025)\end{array}$ & $\begin{array}{c}0.001 \\
(0.005)\end{array}$ \\
\hline Unemployed & $\begin{array}{c}0.374 \\
(0.346)\end{array}$ & $\begin{array}{c}0.242 \\
(0.227)\end{array}$ & $\begin{array}{c}0.108 \\
(0.160)\end{array}$ & $\begin{array}{c}0.014 \\
(0.029)\end{array}$ \\
\hline Employed Full-Time & $\begin{array}{c}-0.104 \\
(0.111)\end{array}$ & $\begin{array}{l}-0.052 \\
(0.039)\end{array}$ & $\begin{array}{l}-0.039 \\
(0.074)\end{array}$ & $\begin{array}{l}-0.009 \\
(0.011)\end{array}$ \\
\hline Constant & $\begin{array}{c}-1.272 * * * \\
(0.276)\end{array}$ & $\begin{array}{c}-0.657 * * * \\
(0.207)\end{array}$ & $\begin{array}{c}-0.451^{*} \\
(0.241)\end{array}$ & $\begin{array}{c}-0.153 * * * \\
(0.042)\end{array}$ \\
\hline $\begin{array}{l}N \\
\text { R-squared }\end{array}$ & $\begin{array}{l}1,704 \\
0.217\end{array}$ & $\begin{array}{l}1,704 \\
0.129\end{array}$ & $\begin{array}{l}1,704 \\
0.194\end{array}$ & $\begin{array}{l}1,704 \\
0.080\end{array}$ \\
\hline
\end{tabular}

OLS with robust standard errors clustered by region in parentheses.

Column headings reflect dependent variable in each model.

$* * * \mathrm{p}<0.01, * * \mathrm{p}<0.05, * \mathrm{p}<0.1$ 
Table 3. Determinants of Additional Dimensions of EU Participation

\begin{tabular}{|c|c|c|}
\hline & $\begin{array}{c}(5) \\
\text { Protest } \\
\text { Against EU }\end{array}$ & $\begin{array}{c}\text { (6) } \\
\text { Did } \\
\text { Nothing } \\
\end{array}$ \\
\hline \multicolumn{3}{|l|}{ Identity Variables } \\
\hline Local Identification & $\begin{array}{c}0.065 \\
(0.103)\end{array}$ & $\begin{array}{c}0.109 \\
(0.084)\end{array}$ \\
\hline Regional Identification & $\begin{array}{c}0.047 \\
(0.160)\end{array}$ & $\begin{array}{c}-0.105 \\
(0.065)\end{array}$ \\
\hline National Identification & $\begin{array}{c}0.058 \\
(0.197)\end{array}$ & $\begin{array}{c}-0.165 * * * \\
(0.050)\end{array}$ \\
\hline European Identification & $\begin{array}{l}-0.142 \\
(0.091)\end{array}$ & $\begin{array}{c}0.023 \\
(0.048)\end{array}$ \\
\hline \multicolumn{3}{|l|}{ Economic Variables } \\
\hline Egocentric Index & $\begin{array}{l}-0.074 \\
(0.215)\end{array}$ & $\begin{array}{l}-0.069 \\
(0.152)\end{array}$ \\
\hline Sociotropic Index & $\begin{array}{l}-0.298 \\
(0.398)\end{array}$ & $\begin{array}{c}-0.008 \\
(0.160)\end{array}$ \\
\hline \multicolumn{3}{|l|}{ Political Variables } \\
\hline EU Support Index & $\begin{array}{c}-0.382 * * \\
(0.188)\end{array}$ & $\begin{array}{c}-0.267 * * * \\
(0.078)\end{array}$ \\
\hline Current EU Direction & $\begin{array}{l}-0.013 \\
(0.121)\end{array}$ & $\begin{array}{c}0.329 * * * \\
(0.039)\end{array}$ \\
\hline L-R Ideology & $\begin{array}{c}0.081 \\
(0.080)\end{array}$ & $\begin{array}{c}-0.010 \\
(0.060)\end{array}$ \\
\hline Political Interest & $\begin{array}{c}0.096 \\
(0.136)\end{array}$ & $\begin{array}{c}-0.181 * * * \\
(0.045)\end{array}$ \\
\hline Follow News & $\begin{array}{c}0.093 \\
(0.168)\end{array}$ & $\begin{array}{l}-0.116^{*} \\
(0.064)\end{array}$ \\
\hline PM Approval & $\begin{array}{l}-0.034 \\
(0.106)\end{array}$ & $\begin{array}{c}0.054 \\
(0.059)\end{array}$ \\
\hline \multicolumn{3}{|l|}{ Sociodemographics } \\
\hline Male & $\begin{array}{c}0.715 * * \\
(0.354)\end{array}$ & $\begin{array}{c}-0.178 \\
(0.163)\end{array}$ \\
\hline Education & $\begin{array}{c}0.298 * * \\
(0.118)\end{array}$ & $\begin{array}{c}-0.297 * * * \\
(0.072)\end{array}$ \\
\hline Age & $\begin{array}{c}0.009 \\
(0.010)\end{array}$ & $\begin{array}{c}-0.021 * * * \\
(0.006)\end{array}$ \\
\hline Occupational Prestige & $\begin{array}{c}0.094 \\
(0.147)\end{array}$ & $\begin{array}{c}-0.366 * * * \\
(0.085)\end{array}$ \\
\hline Rural-Urban Residence & $\begin{array}{c}0.074 \\
(0.172)\end{array}$ & $\begin{array}{c}0.022 \\
(0.076)\end{array}$ \\
\hline Unemployed & $\begin{array}{c}0.307 \\
(1.342)\end{array}$ & $\begin{array}{c}0.555 \\
(0.401)\end{array}$ \\
\hline Employed Full-Time & $\begin{array}{l}-0.088 \\
(0.357)\end{array}$ & $\begin{array}{c}0.302 \\
(0.242)\end{array}$ \\
\hline Constant & $\begin{array}{c}-5.960 * * * \\
(1.265)\end{array}$ & $\begin{array}{c}2.404 * * * \\
(0.881)\end{array}$ \\
\hline$N$ & 1,704 & 1,704 \\
\hline Pseudo R-squared & 0.115 & 0.174 \\
\hline
\end{tabular}

Ordered logit with robust standard errors clustered by region in parentheses.

Column headings reflect dependent variable in each model.

$$
{ }^{* * *} \mathrm{p}<0.01,{ }^{* *} \mathrm{p}<0.05,{ }^{*} \mathrm{p}<0.1
$$


Figure 1. Distribution of Responses to EU Participation Items

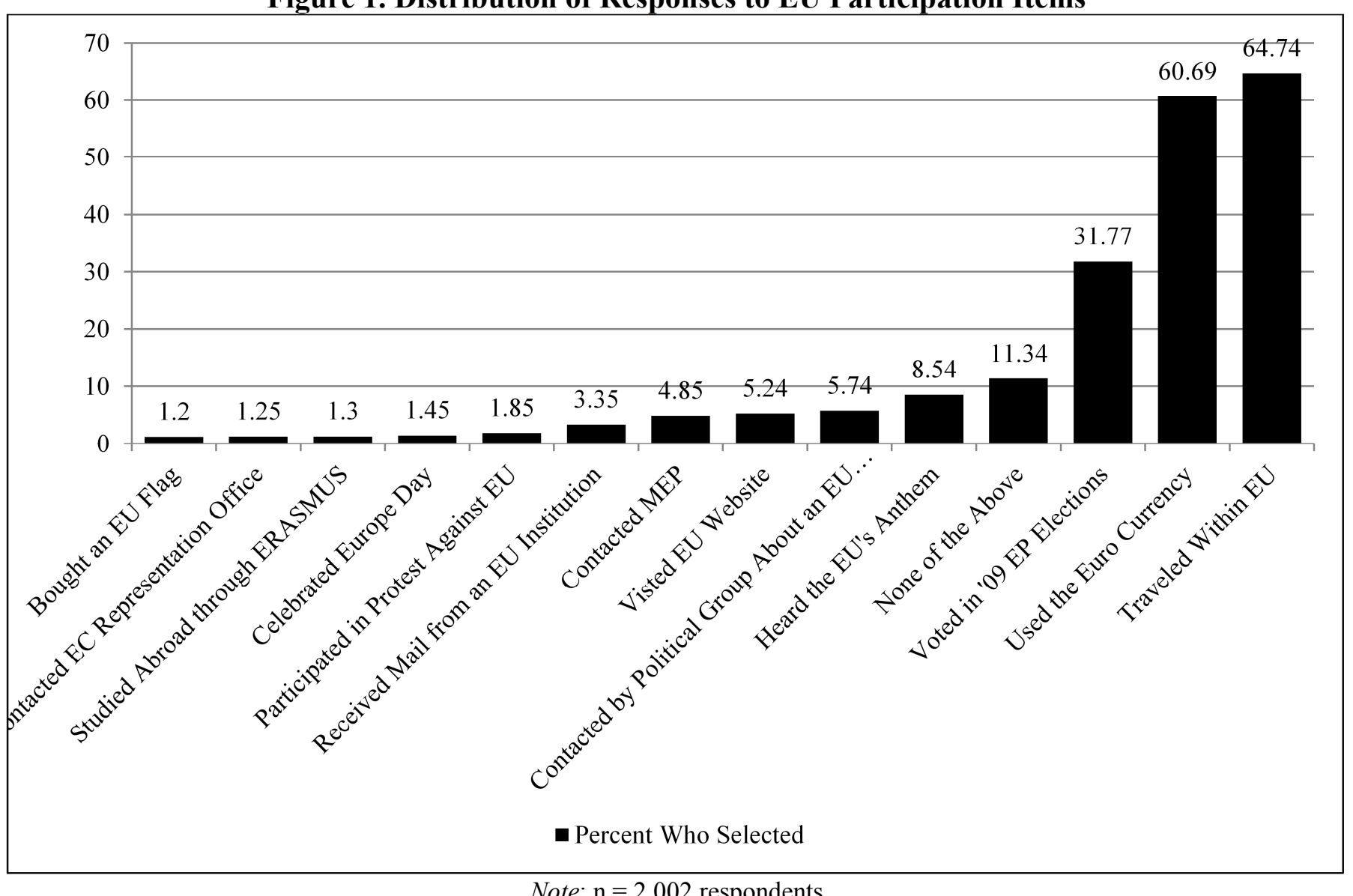

Note: $\mathrm{n}=2,002$ respondents 
Figure 2. Range and Frequency of EU Participation

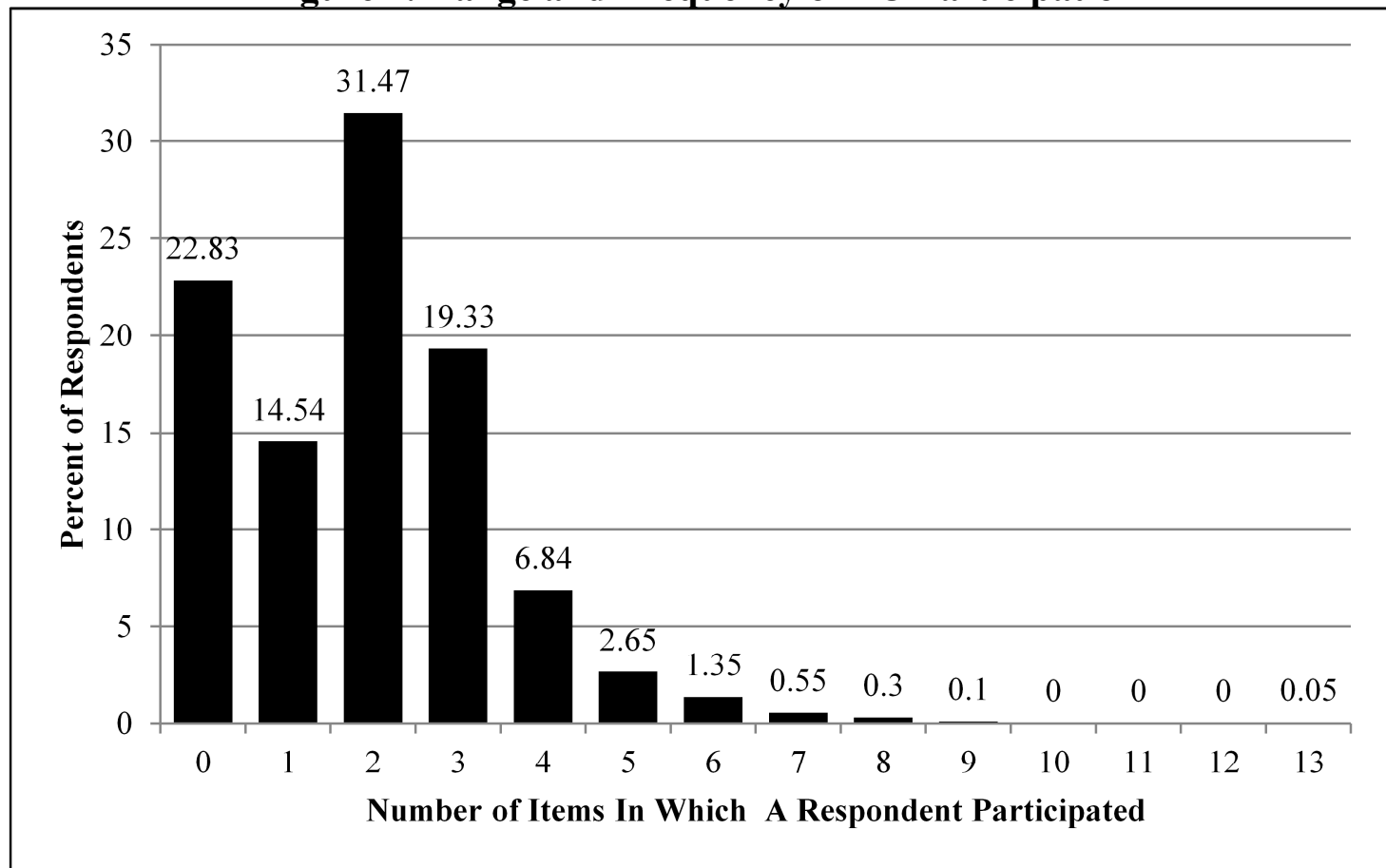

Note: $\mathrm{n}=2,002$ respondents 
Figure 3. Magnitude of Effects for Determinants of Additive Index

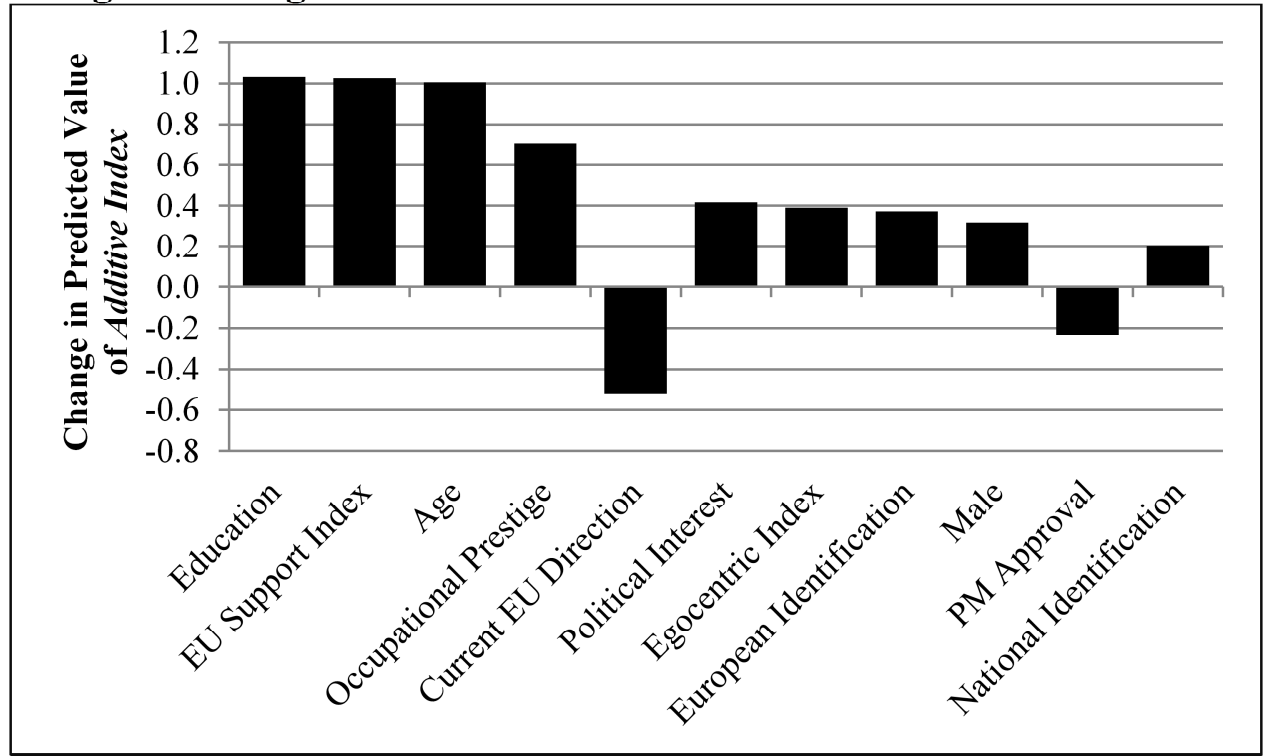

Bars indicate the substantive impact of moving from the minimum to maximum on each variable, holding all else at its mean.

Calculated using Long and Freese's (2006) spost commands in Stata.

Only variables passing the $\mathrm{p} \leq .05$ significance threshold in Table 2, Model 1 listed.

Figure 4. Magnitude of Effects for Determinants of Info-Seeking

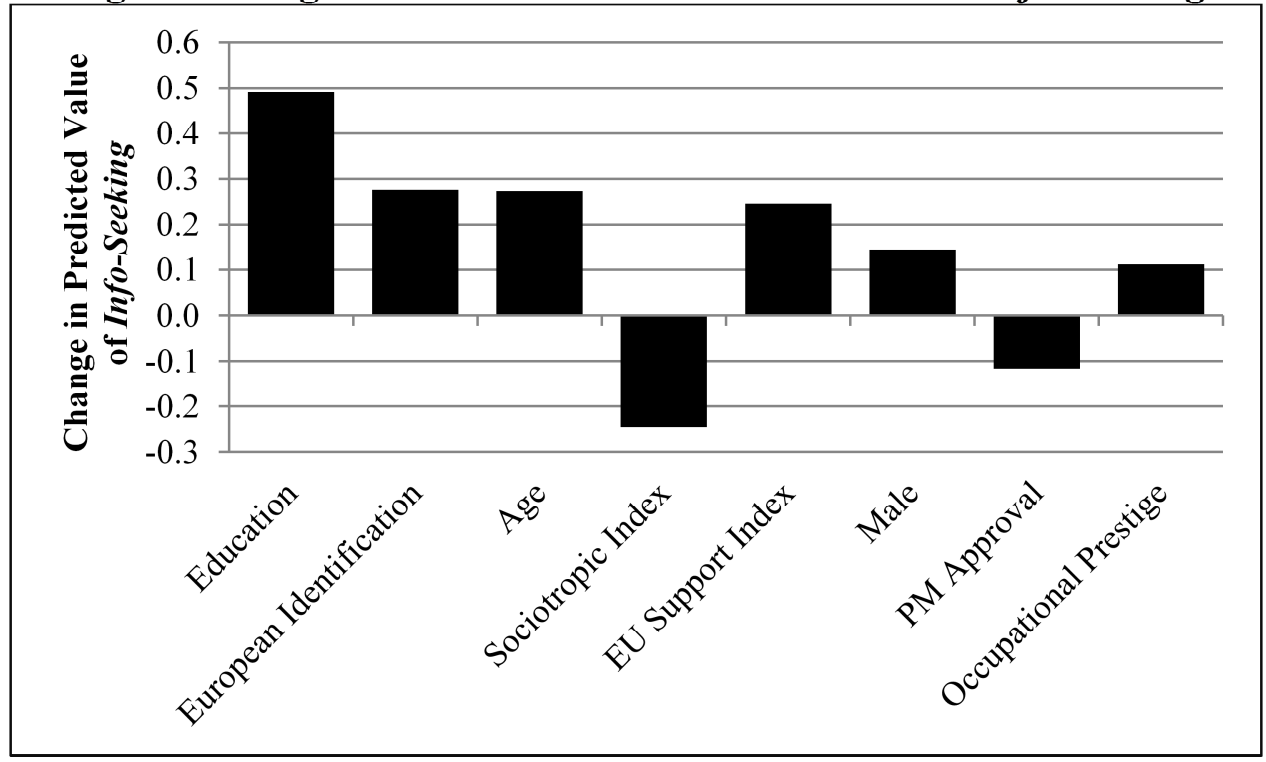

Bars indicate the substantive impact of moving from the minimum

to maximum on each variable, holding all else at its mean.

Calculated using Long and Freese's (2006) spost commands in Stata.

Only variables passing the $\mathrm{p} \leq .05$ significance threshold in Table 2, Model 2 listed. 
Figure 5. Magnitude of Effects for Determinants of Take Advantage

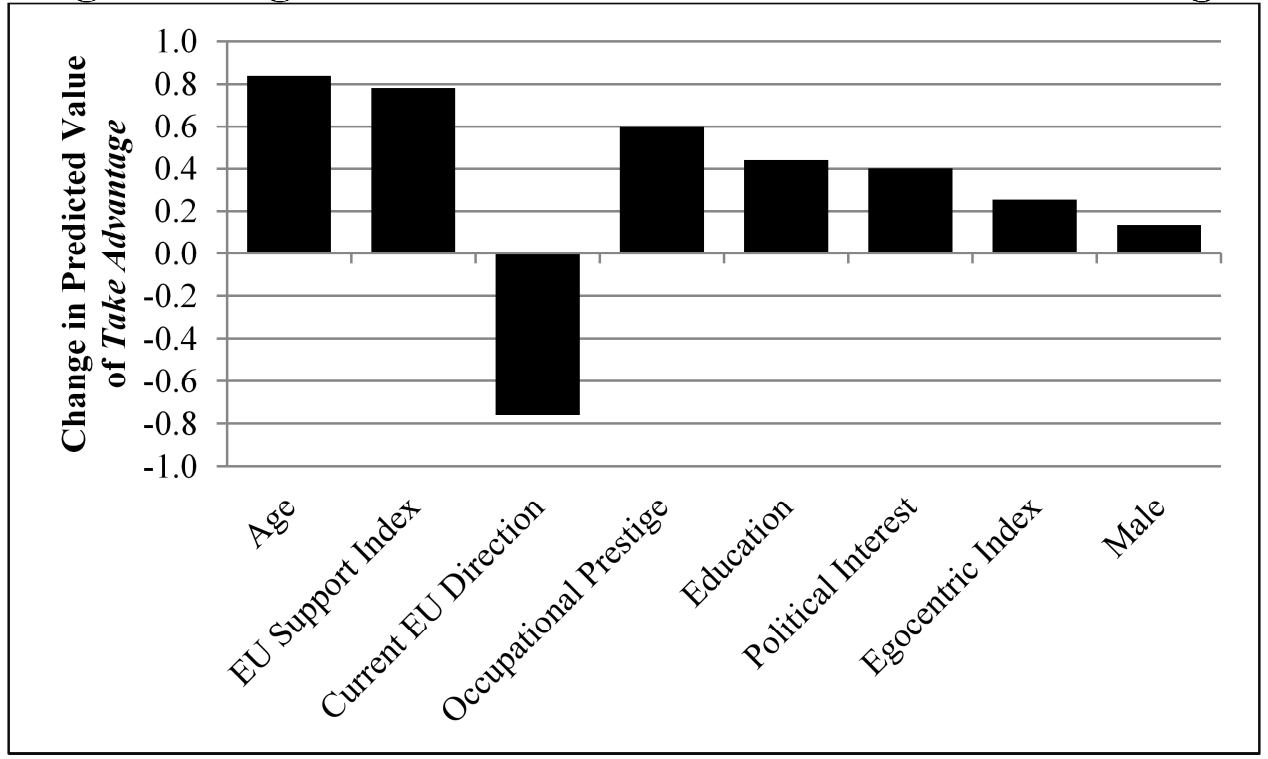

Bars indicate the substantive impact of moving from the minimum to maximum on each variable, holding all else at its mean.

Calculated using Long and Freese's (2006) spost commands in Stata.

Only variables passing the $\mathrm{p} \leq .05$ significance threshold in Table 2, Model 3 listed.

Figure 6. Magnitude of Effects for Determinants of Show EU Pride

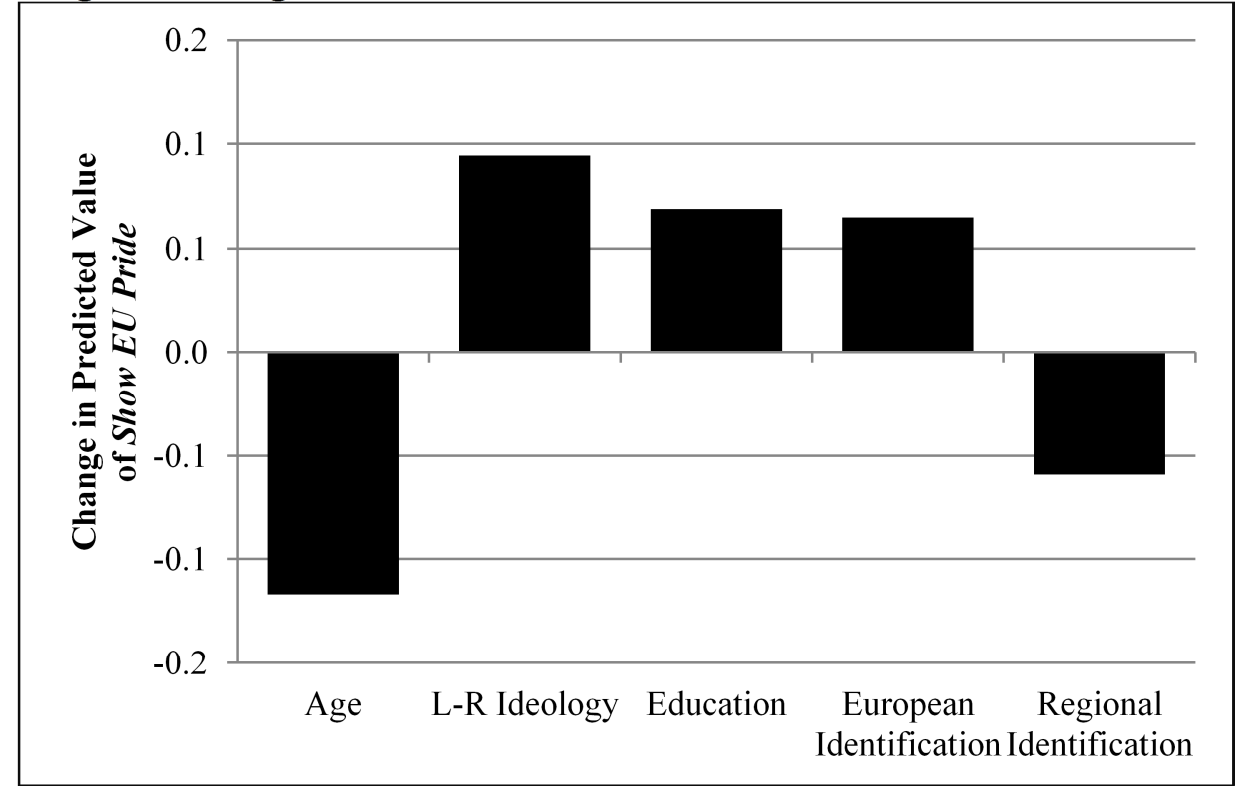

Bars indicate the substantive impact of moving from the minimum to maximum on each variable, holding all else at its mean.

Calculated using Long and Freese's (2006) spost commands in Stata.

Only variables passing the $\mathrm{p} \leq .05$ significance threshold in Table 2, Model 4 listed. 
Figure 7. Magnitude of Effects for Determinants of Protest Against EU

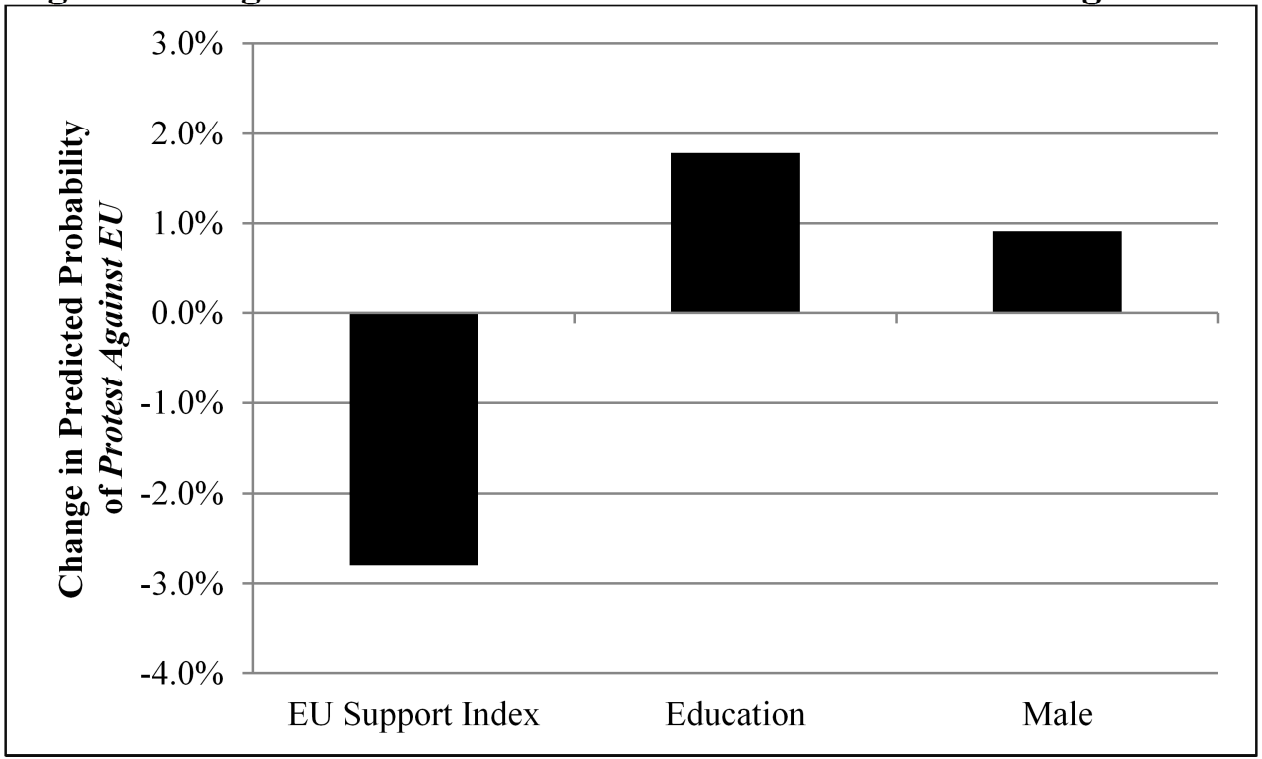

Bars indicate the substantive impact of moving from the minimum to maximum on each variable, holding all else at its mean.

Calculated using Long and Freese's (2006) spost commands in Stata. Only variables passing the $\mathrm{p} \leq .05$ significance threshold in Table 3 , Model 5 listed.

Figure 8. Magnitude of Effects for Determinants of Did Nothing

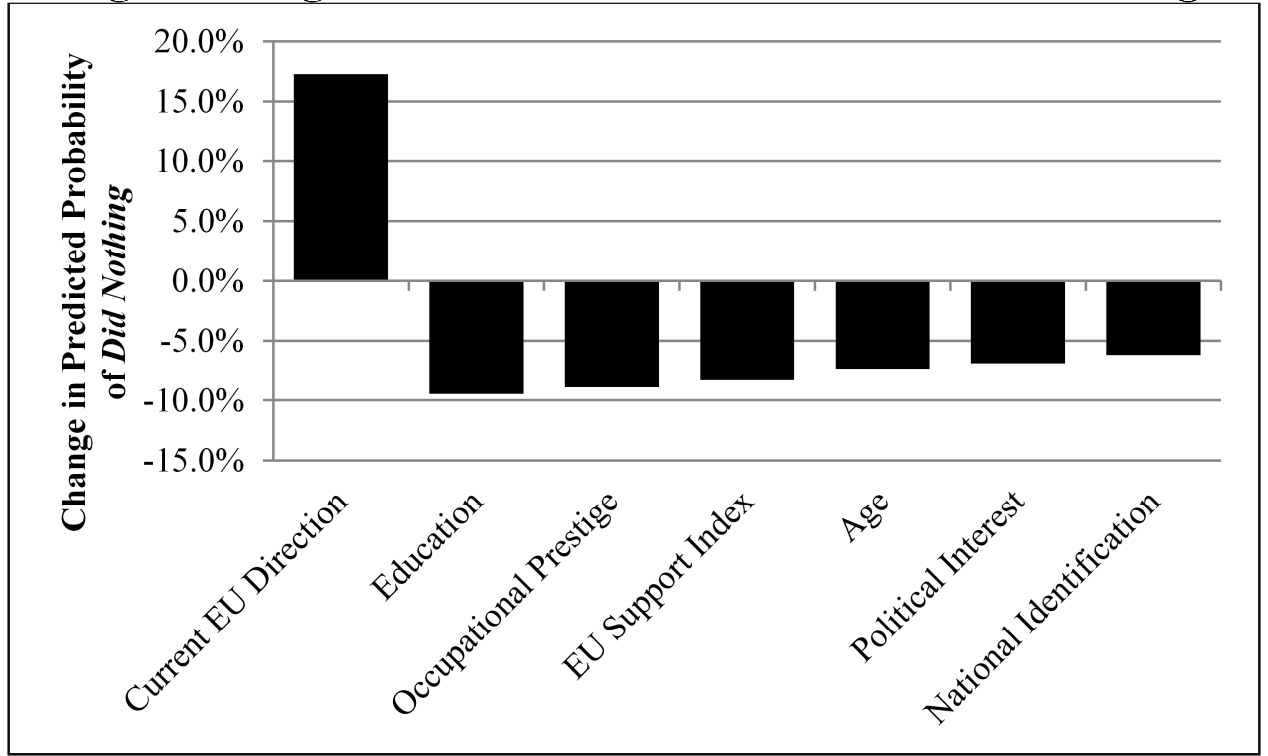

Bars indicate the substantive impact of moving from the minimum to maximum on each variable, holding all else at its mean.

Calculated using Long and Freese's (2006) spost commands in Stata. Only variables passing the $\mathrm{p} \leq .05$ significance threshold in Table 3 , Model 6 listed. 